\title{
Evaluasi Akuntanbilitas Pengelolaan Dana Desa Smber Salak Kecamatan Ledokombo Kabupaten Jember
}

\section{Imam Subki Arifi*}

Universitas Muahammadiyah Jember, Jawa Timur, Indonesia

\section{A R T I C L E I N F O}

Article history:

Received 19 May 2019

Received in revised form

16 June 2019

Accepted 15 July 2019

Available online 26 August 2019

\section{Kata Kunci:}

Akuntansi Keuangan

Keywords:

Financial Accounting

\begin{abstract}
A B S T R A K
Indonesia merupakan negara yang memiliki wilayah yang sangat luas yang terdiri dari beberapa provinsi, di setiap provinsi dibagibagi menjadi beberapa tingkatan wilayah yaitu kabupaten atau kota yang juga terbagi menjadi kecamatan, dimana kecamatan ini dibagi lagi menjadi wilayah yang lebih kecil yaitu kelurahan dan desa. Untuk meningkatkan pembangunan di desa. Kepala Desa dan anggota dari perangkat desa dan didampingi oleh badan permusyawaratan desa mengadakan evaluasi dalam anggaran yang sudah terealisasi dan dilihat fisik yang ada apakah sudah sesuai dengan apa yang sudah dianggarkan, dialokasikan.
\end{abstract}

\section{A B S T R A C T}

Indonesia is a country that has a very large area consisting of several provinces, in each province divided into several levels, namely districts or cities which are also divided into sub-districts, where the sub district further divided into smaller areas, kelurahan and villages to increase development in the village. The Village Head and members of the village apparatus and accompanied by the village consultative body conduct an evaluation in the budget that has been realized and see whether the existing physical is in accordance with what has been budgeted, allocated.

\footnotetext{
* Corresponding author.

E-mail addresses: imamsarifi25@gmail.com (Imam Subki Arifi)
} 


\section{Pendahuluan}

Indonesia merupakan negara yang memiliki wilayah yang sangat luas yang terdiri dari beberapa provinsi, di setiap provinsi dibagi-bagi menjadi beberapa tingkatan wilayah yaitu kabupaten atau kota yang juga terbagi menjadi kecamatan, dimana kecamatan ini dibagi lagi menjadi wilayah yang lebih kecil yaitu kelurahan dan desa. Untuk meningkatkan pembangunan di desa, pemerintah Indonesia telah berupaya membuat program pemberdayaan desa dimana diharapkan perangkat desa bersama masyarakatnya dapat secara mandiri bekerjasama untuk membangun dan memajukan desa tempat mereka tinggal tentunya dibawah pengawasan pemerintah kabupaten (Aldera, 2014).

Kabupaten Jember merupakan salah satu daerah yang menerima anggaan dana desa yang selanjutnya akan disalurkan ke setiap kecamatan yang ada di Kabupaten Jember. Menurut Peraturan Daerah Kabupaten Jember Nomor 5 Tahun 2016, Tentang Pengelolaan Kekayaan Milik Desa Bahwa (1) Dana desa dikelola dalam Anggaran Pendapatan dan Belanja Desa (APBDes) dan digunakan untuk membiayai kegiatan penyelenggaraan pemerintah desa, pelaksanaan pembangunan desa, pembinaan kemasyarakatan, pemberdayaan masyarakat dan bidang yang tidak terduga (2) Dana desa diprioritaskan untuk membiayai kegiatan bidang penyelenggaraan pemerintah desa, bidang pemberdayaan masyarakat dan bidang pelaksanaan pembangunan desa (3) Pemerintah desa menyusun bentuk kegiatan yang dibiayai dana desa dengan mengacu pada dokumen Rencana Pembangunan Jangka Mengah (RPJMDes) dan Rencana Kerja Pemerintah Desa (RKPDes) (4) Contoh bentuk kegiatan sebagaimana dimaksud pada ayat (3) sebagaimana tercantum dalam lampiran 1 yang merupakan bagian tidak terpisahkan dari peraturan Bupati ini.

Adapun rumusan masalah yang penulis rumuskan dari hasil penelitian sebagai berikut : (1) Mengevaluasi akuntanbilitas dan pengelolaan dana desa yang ada di Desa Sumber Salak Kecamatan Ledokombo?, (2) Apakah pengelolaan Dana Desa yang ada di Desa Sumber Salak sudah sesuai dengan akuntanbilitas pengelolaan Dana Desa menurut Undang - Undang Nomor 6 Tahun 2014? (3) Membandingkan akuntanbilitas pengelolaan dana desa dengan Undang - undang Nomor 6 Tahun 2014?

Adapun tujuan penelitian yang penulis cantumkan dari penelitian sebagai berikut : (1) Mendeskripsikan dan menganalisis akuntanbilitas dana desa dan pengelolaan dana desa sudah mengikuti peraturan Undang-undang Nomor 6 Tahun 2014. (2) Untuk mengetahui apakah pengelolaan akuntanbilitas dan pengelolaan dana desa sudah sesuai dengan Undang - undang Nomor 6 Tahun 2014. (3) Membandingkan perencanaan dan pengelolaan akuntanbilitas dana desa dengan Undang - Undang Nomor 6 Tahun 2014.

Evaluasi adalah suatu usaha untuk mengukur dan sumber nilai secara objektif dari pencapaian hasil-hasil yang direncanakan sebelumnya, dimana hasil evaluasi tersebut dimaksudkan menjadi umpan balik untuk perencanaan yang akan dilakukan di depan.

Akuntanbilitas adalah kemampuan memberikan jawaban kepada otoritas yang lebih tinggi atas tindakan seseorang/sekelompok orang terhadap masyarakat luas dalam suatu organisasi (Syahrudin Rasul, 2002:8).

Sedangkan menurut United National Development Programme (UNDP), akuntabilitas adalah evaluasi terhadap proses pelaksanaan kegiatan/kinerja organisasi untuk dapat dipertanggungjawabkan serta sebagai umpan balik bagi pimpinan organisasi untuk dapat lebih meningkatkan kinerja organisasi pada masa yang akan datang. Akuntabilitas merupakan konsep yang komplek yang lebih sulit mewujudkannya dari pada memberantas korupsi. Akuntabilitas adalah keharusan lembaga-lembaga sektor publik untuk lebih menekan pada pertanggungjawaban horizontal (masyarakat) bukan hanya pertanggungjawaban vertikal (otoritas yang lebih tinggi), (Turner and Hulme, 1997).

Dana desa adalah yang bersumber dari anggaran pendapatan belanja negara yang diperuntukkan bagi desa yang ditransfer melalui Anggaran Pendapatan Belanja Daerah Kabupaten/Kota dan digunakan untuk membiayai penyelenggaraan pemerintah, pelaksanaan pembangunan, pembinaan kemasyarakatan dan pemberdayaan masyarakat (Peraturan Pemerintah Nomer 60 tahun 2014).

\section{Metode}

Penelitian ini adalah analisa deskriptif dengan pendekatan kualitatif. Sanusi (2011:13) berpendapat bahwa, desain penelitian deskriptif adalah desain penelitian yang disusun dalam rangka memberikan gambaran secara sistematis tentang informasi ilmiah yang berasal dari subyek atau obyek penelitian. Penelitian deskritif berfokus pada penjelasan sistematis tentang fakta yang diperoleh saat penelitian dilakukan. Penelitian ini terbatas pada usaha pengembangan suatu masalah atau keadaan untuk mengungkapkan fakta. Hasil penelitian ditekankan pada gambaran secara obyektif tentang keadaan sebenarnya dari obyek yang diteliti. 
Sumber data dalam penelitian ini dilakukan dengan dua cara yaitu: (1) Data Primer, merupakan sumber data penelitian yang diperoleh secara langsung dari sumbernya. Dalam penelitian ini data primer diperoleh dari penelusuran langsung dan melalui wawancara dengan pihak Desa Sumber Salak. (2)Data Sekunder, merupakan data yang diperoleh peneliti secara tidak langsung pada data sekunder ini penulis memperoleh catatan yang akan dianalisis dan evaluasi bersama dengan data primer.

Teknik pengumpulan data yang digunakan dalam penelitian ini adalah sebagai berikut : (1) Wawancara terstruktur merupakan pengumpulan data dimana peneliti mengajukan pertanyaan kepada pihak desa dalam bentuk lisan yang telah disiapkan berupa pertanyaan-pertanyaan. Peneliti dapat berbicara berhadapan langsung dengan kepada pihak desa, sekretaris desa, bendahara desa dan prangkat desa lainnya. (2) Dokumentasi merupakan metode yang dilaksanakan oleh peneliti untuk mencari data mengenai variabel yang berupa catatan, transkip, agenda dan menghasilkan dokumen yang berisi suatu kegiatan di Desa Sumber Salak.

\section{Hasil dan pembahasan}

Penelitian ini dilakukan di Desa Sumber Salak Kecamatan Ledokombo Kabupaten Jember. Desa Sumber Salak merupakan desa kecil yang ada di Kabupaten Jember Provinsi Jawa Timur, Dengan batas desa sebagai berikut: (1) Sebelah Utara berbatasan dengan Desa Sumber Lesung. (2) Sebelah Barat berbatasan dengan Desa Suren. (3) Sebelah Selatan berbatasan dengan Desa Kajar

Berdasarkan data administrasi pemerintah desa Tahun 2017 jumlah penduduk Desa Sumber Salak adalah 7112 jiwa yang terdiri dari 4539 laki-laki, 2573 perempuan dan 2395 kepala keluarga, Desa Sumber Salak terdiri dari 5 dusun. Jumlah penduduk sangat penting untuk dipertimbangkan karena penduduk merupakan subyek pembangunan dan dan menjadi sasaran dari pembangunan. Peran aktif masyarakat dalam pembangunan dibangkitkan lewat organisasi sistem yang ada di desa Sumber Salak.

Keuangan Desa Sumber Salak bersumber dari berbagai aspek, ada yang dari luar Desa maupun berasal dari dalam Desa Sumber Salak itu sendiri, ada tiga macam keuangan Desa yaitu PAD (Pendapatan Asli Daerah), DD (Dana Desa), ADD (Alokasi Dana Desa) berikut penjelasanya:

1. PAD (Pendapatan Asli Desa)

a. Hasil Aset (Sewa tanah kas Desa).

b. Swadaya, Pertisipasi dan gotong royong.

c. Pasar Desa (Pendapatan asli Desa yang sah)

2. Pendapatan Transfer

a. Dana Desa

b. Bagian Dari hasil pajak dan retribusi daerah Kabupaten/Kota

i. Bagi hasil Pajak Daerah

ii. Bagi Hasil Retribusi Daerah

c. Alokasi Dana Desa

d. Bantuan keuangan

iii. Bantuan Provinsi

iv. Bantuan Kabupaten/Kota

3. Pendapatan Lain-lain

a. Hibah dan sumbangan Pihak ke-3 yang tidak mengikat

b. Lain-lain pendapatan Dana Desa yang sah

Dalam melakukan perencanaan Desa Sumber Salak harus fokus terhadap pembangunan yang memang di rencanakan oleh pihak Desa Sumber Salak, misal dalam perencanaan dan pengajuan Desa Sumber Salak memperbaiki jalan yang rusak yang ada di Desa Sumber Salak Dana yang di dapat dari pemerintah pusat akan digunakan untuk perbaikan Jalan yang ada di Desa.

Tingkat akuntanbilitas dalam implementasi pengelolaan dana desa di mulai dari tahap perencanaan, pelaksanaan dan pertanggungjawaban. Sebagaimana ketentuan dalamPeraturan Bupati No.7 Tahun 2016 tentang pedoman umum Pelaksanaan Pengelolaan Dana Desa di Kebupaten Jember Tahun 201, menyebutkan bahwa prinsip pengelolaan sebagai berikut: (a) Rencana kegiatan dirumuskan melalui musyawarah desa dan tuangkan dalam APB Desa, sehingga secara transparan diketahui masyaraka. (b) Pelaksanaan kegiatan pembangunan di Desa maupun dusun dapat lebih mencapai daya guna dan hasil guna perlu dukuangan swadaya masyarakat yang besarnya disesuaikan dengan kemampuan masyarakat desa. (c) Seluruh pelaksanaan kegiatan harus dapat dipertanggungjawabkan baik secara teknis maupun administrasi yait harus dilengkapi dengan Rencana Kerja dan Anggaran (RKP), gambar bangunan dan Rencana Anggaran Biaya (RKP) dari institusi teknis atau jasa pihak ketiga.

Pelaksanaan pengelolaan Dana Desa dengan menggunakan prinsip hemat, terarah dan terkendali. 
Perencanaan Dana Desa (DD) Desa Sumber Salak pada tahun anggaran 2017 ini juga telah ditentukan prioritas program yang akan dilaksanakan yaitu program pembangunan fisik desa, karena sebelum tahun 2017 Desa Sumber Salak sudah melakukan Musdus di 4 dusun untuk mengetahui pembangunan apa yang dibutuhkan oleh setiap dusun yang ada di Desa Sumber Salak, setelah di dapat yang di butuhkan untuk setiap dusun hasil dari musdus di bawak ke Murembangdes dari situ Desa Sumber Salak membentuk RPJMDes dan RKPBDes, dan juga menentukan berapa dana yang dibutuhkan untuk pembangunan Desa yang direncanakan.

Pengalokasian yang dilakukan Pihak Desa Sumber Salak. Setelah Dana yang di transfer dari Pemerintah Pusat ke pemerintah Desa dalam melakukan pengalokasianya Desa melakukan Musyawarah dengan perangkat Desa atau pun dengan masyarakat Desa yang ada di Desa Sumber salak agar Dana yang di terima oleh Pihak Desa di ketauhi oleh seluruh elemen yang ada di Desa Sumber Salak tersebut agar supaya tidak ada kesalahan ataupun disalahgunakan oleh pihak Desa, Desa harus melakukan pembangunan seperti yang sudah disusun dalam RKPBDes jika ada hal yang tidak diinginkan seperti ambruknya jembatan maka pemerintah Desa akan menggunakan Dana Desa tersebut dengan merubah RKPBDes yang di sebut RKPBDes perubahan.

Berdasarkan hasil wawancara di atas dapat dismpulkan bahwa apabila tahap pertama ada sisa dan sisa tersebut masuk dalam kas desa secara otomatis dan apabila dana tersebut kurang dalam pembangunan dari dana yang cair tahap satu, pembangunan tersebut berhenti atau macet dan menunggu pembangunan tahap ke II harus menyertakan persyaratan mulai dari perencanaan melalui RKPDes, RPJMDes sampai kepermohonan percairan tahap berikutnya. Dalam melakukan pembangunan Desa, Desa bekerjasama dengan Masyarakatdesa untuk ekonomi masyarakat Desa Sumber Salak, dengan menggunakan tenaga asli yang ada di Desa akan meningkatkan SDM yang ada di Desa Sumber Salak itu sendiri.

Dalam membuat laporan Dana Desa yang terjadi di Desa Sumber Salak terlebih dahulu Desa Sumber Salak melakukan evaluasi Dana Desa terutama Dana Desa, dalam melakukan evaluasi perangkat Desa dan juga masyarakat Desa melakukan musyawarah apakah terjadi kesalahan ataupun keterlambatan dalam penganggaran, pengalokasian yang didampingi oleh BPD (Badan Permusyawaratan Desa) baru setelah itu pemerintah Desa Sumber Salak membuat laporan yang terjadi di Desa Sumber Salak selama 1 tahun anggaran.

Laporan yang disampaikan Kepada Badan Permusyawaratan Desa (BPD): Laporan keterangan Pertanggungjawaban Realisasi Pelaksanaan Anggaran pendapatan dan Belanja Desa yang terdiri dari pendapatan Desa, Belanja Desa, dan pembiayaan Desa. Hal in juga disampaikan oleh Ibuk Suparmi Selaku Kepala Desa Sumber Salak. Laporan pertanggungjawaban realisasi pelaksanaan Dana Desa disampaikan ke TPK, nanti TPK nya seperti bahan dia pesan sama satu toko yang sudah ada dokumen sendiri tentang bahan yang ada di RAB dan ada juga ongkos tukang, untuk bahan, honor untuk proyek.

Mekanisme pengawasan dan evaluasi penggunaan Dana Desa Sumber Salak adalah penetapan prioritas penggunaan Dana Desa dilaksanakan dengan pendekatan pemberdayaan masyarakat desa. Intinya adalah masyarakat yang ada di Desa Sumber Salak didampingi untuk terlibat aktif dalam penetapan prioritas penggunaan Dana Desa, sehingga Dana Desa dipastikan membiayaai kegiatankegiatan yang dibutuhkan oleh masyarakat Desa Sumber Salak. Ada 3 pengawasan yang dilakukan pemerintah terhadap Desa Sumber Salak yaitu:

1. Pemerintah Provinsi dan Kabupaten/Kota wajib membina dan mengawasi pelaksanaan penggunaan Dana Desa.

2. Pembinaan dana pengawasan pemerintah provinsi dan Kabupaten/Kota meliputi:

a. Menetapkan pengaturan yang berkaitan dengan Dana Desa.

b. Membuat pedoman teknis kegiatan yang dapat didanai dari Dana Desa.

c. Melakukan evaluasi dan pengawasan pelaksanaan penggunaan Dana Desa dan

d. Memberikan bimbingan, supervisi dan konsultasi pelaksanaan pengelolaan dan penggunaan Dana Desa.

3. Pembinaan dan pengawasan camat meliputi:

a. Memfasilitasi penggunaan dan pengelolaan Dana Desa

b. Memberikan Bimbingan, supervisi dan konsultasi terkait penggunaan dan pengelolaan Dana Desa dan,

c. Melakukan pengawasan penggunaan dan pengelolaan Dana Desa.

Dalam melakukan pengawasan penggunaan keuangan Desa Sumber Salak sudah ada tim khusus untuk melakukan pengawasan ataupun mengevaluasi kegiatan selama 1 tahun yang dilakukan Desa Sumber salak yaitu pihak BPD dan juga pihak yang berasal dari Kecamatan Ledokombo lalu pemerintah Desa melakukan musyawarah Desa yaitu (MUSREMBANGDES) Dari situ akan dibahas Dana Desa yang 
ditransfer dibuat apa saja dan juga hasil dari pembangunan Desa Sumber Salak akan didapat hasil yang memuaskan dari pemerintah Desa khususnya masyarakat Desa dan juga Pemerintah Pusat.

Sasaran penggunaan Dana Desa yang diserahkan Kepada Pemerintah Desa dan Lembaga Kemasyarakatan yang mengacu pada hasil Musyawarah Rencana Pembangunan Desa (Musrembangdes) melalui proses Perencanaan partisipatif. Kegiatan evaluasi bertujuan untuk mengetauhi sejauh mana tahap-tahap pembangunan yang dilaksanakan dengan penggunaan dana desa. Kegiatan evaluasi biasanya dilakukan sekali dalam setahun pada ahir tahun dan tanpa pemberitahuan terlebih dahulu. Pengawasan dan evaluasi bertujuan untuk menjunjung tinggi sehingga masyarakat bisa bebas mengawasi, mengevaluas, mendapatkan informasi mengenai Dana Desa. Hal ini juga di sampaikan oleh ibuk Suparmi selaku Sekretaris Desa Dengan adanya evalusi tentunya apa yang tidak baik saya sendiri berupaya bagaimana menjadi baik dari administrasi dari pembangunannya. Sebenernya kalou dipembangunan saya tidak ada hak, pernah secara undang-undang yang ada saya sendiri diketua PTPKD itu hanya pengelolaan keuanganya untuk langsung ke proyeknya. Kendalanya biasanya kalou pembangunanya tidak selesai atau pembangunan jauh tidak sama dengan apa yang di Rencana Anggaran Biaya (RAB), itupun kalou masyarakat dan Badan Permusyawaratan Desa (BPD) tau dan yang jelas bagi pembangunan misalnya tidak sampai $40 \%$ padahal pencairan $40 \%$ otomatis kami mencairkan tahap berikutnya kami juga sulit karena pihak yang memberi tentang sejauh pembangunan harus imbang, dana yang turun $40 \%$ kalou pembangunan tidak sampai $40 \%$ tidak mungkin bisa.

Dalam penjelasan yang dilakukan Skretaris Desa bahwasanya Dalam melakukan tidak semua yang dilakukan Desa Sumber Salak sesuai dengan yang direncanakan khusunya dalam Pembangunan Desa. Berdasarkan hasil wawancara tersebut dapat diketauhi bahwa evaluasi penggunaan dana desa sangat diperlukan untuk mengetauhi apakah pelaksanaan pembangunan desa sudah sesuai dengan perencanaanya dan apakah sudah tercapai sesuai dengan target yang ditetapkan. Selain itu, evaluasi sebagai bentuk pertanggungjawaban dan menginformasikan kepada BPD dan masyarakat tentang pelaksanaan pembangunan yang didanai dengan Dana Desa. Berdasarkan dengan adanya evaluas, desa Sumber Salak mengadakan evaluasi tim pelaksana kegiatan dengan mengundang beberapa pihak yang memilki kepentingan.

Kegiatan evaluasi bertujuan untuk mengetauhi sejauh mana tahap-tahap pembangunan yang dilaksanakan dengan penggunaan dana desa. Kegiatan evaluasi biasanya dilakukan sekali dalam setahun pada ahir tahun dan tanpa pemberitahuan terlebih dahulu. Pengawasan dan evaluasi bertujuan untuk menjunjung tinggi sehingga masyarakat bisa bebas mengawasi, mengevaluas, mendapatkan informasi mengenai Dana Desa. Hal ini juga di sampaikan oleh ibuk Suparmi selaku Sekretaris Desa dengan adanya evalusi tentunya apa yang tidak baik saya sendiri berupaya bagaimana menjadi baik dari administras dari pembangunannya. Sebenernya kalou dipembangunan saya tidak ada hak, pernah secara undang-undang yang ada saya sendiri diketua PTPKD itu hanya pengelolaan keuanganya untuk langsung ke proyeknya. Kendalanya biasanya kalou pembangunanya tidak selesai atau pembangunan jauh tidak sama dengan apa yang di Rencana Anggaran Biaya (RAB), itupun kalou masyarakat dan Badan Permusyawaratan Desa (BPD) tau dan yang jelas bagi pembangunan misalnya tidak sampai $40 \%$ padahal pencairan $40 \%$ otomatis kami mencairkan tahap berikutnya kami juga sulit karena pihak yang memberi tentang sejauh pembangunan harus imbang, dana yang turun $40 \%$ kalou pembangunan tidak sampai $40 \%$ tidak mungkin bisa.

Berdasarkan hasil wawancara tersebut dapat diketauhi bahwa evaluasi penggunaan dana desa sangat diperlukan untuk mengetauhi apakah pelaksanaan pembangunan desa sudah sesuai dengan perencanaanya dan apakah sudah tercapai sesuai dengan target yang ditetapkan. Selain itu, evaluasi sebagai bentuk pertanggungjawaban dan menginformasikan kepada BPD dan masyarakat tentang pelaksanaan pembangunan yang didanai dengan Dana Desa. Berdasarkan dengan adanya evaluas, desa Sumber Salak mengadakan evaluasi tim pelaksana kegiatan dengan mengundang beberapa pihak yang memilki kepentingan.

\section{Simpulan dan saran}

Berdasarkan hasil analisis dan pembahasan yang peneliti jelaskan maka dapat disimpulkan bahwa Evaluasi tentang pegelolaan dana desa dalam pengelolaan keuangan desa dalam proses pembangunan desa Sumber Salak Kecamatan Ledokombo Kabupaten Jember Tahun 2017 adalah sebagai berikut: Perencanaan dalam pengelolaan Dana Desa di Desa Sumber Salak telah dilakukan dengan baik dan sesuai peraturan yang berlaku. Berdasarkan dalam perencanaan Dana Desa (Musrembangdes) ditingkat Desa, dan Musyawarah Dusun (Musdes) di tingkat Dusun yang melibatkan Badan Permusyawaratan Desa (BPD), Lembaga Pemberdayaan Masyarakat Desa (LPMD), Tim Pengelolaan Kegiatan (TPK) dan tokoh masyarakat. Tujuan dilakukan kegiatan Musrembangdes dan musdus ini adalah untuk menampung 
aspirasi dari semua pihak, baik pemerintah desa, dan dari masyarakat hingga diharapkan pembangunan Desa dilaksanakan sesuai dengan yang direncanakan di dalam Rencana Anggaran Biaya (RAB), tetapi di dalam Rencana Anggaran Biaya (RAB) memiliki angka yang tdak signifikan dengan Dana yang sudah terealisasi penggunaan Dana desa dan yang ada di APBDes. Berdasarkan nilai yang ada didalam Rencana Anggaran Biaya senila Rp. 11.951.269 dengan yang terealisasi di dalam penggunaan Dana Desa dan surat Permintaan Pembayaran (SPP) senilai Rp. 11.935 .793 ada perbedaan hasil ahir yang ada ddalam Rencana Anggaran Biaya (RAB) senilai 199.205 .889 padahal yang ada di Anggaran Belanja Desa senilai 199.190.413 jadi hasil ahir tidak signifikan.

Terkait perbedaan presentase pencairan tahap 1 menurut Peraturan pemerintah Nomor 60 Tahun 2014 presentase sebesar $40 \%$. Selain itu, nominal yang tertera pada pernyataan Tanggungjawab Belanja, surat Permintaan Pembayaran dan Buku Kas Umum Desa sama sebesar Rp 26.841.658 padahal pencatatan presentasenya berbeda.

\section{Daftar Rujukan}

Agustino Leo. 2008 Dasar - dasar Kebijakan Publik. Bandung; Alfabeta

Abdul Wahab, Soliehin. 2000. Analisis Kebijakan dari Formulasi ke Implementasi Kebijakan Negara. Bumi Aksara. Jakarta

Agus Salim. 2002. Perubahan Sosial: Sketsa Teori dan Refrensi Metodologi Kasus di Indonesia. Yogyakarta. PT Tiara Wacana.

Aldera. Antika. 2014. Pengawasan Badan Permusyawaratan Desa terhadap Program Alokasi Dana Desa (Suatu studi di Desa Pak Laheng Kecamatan Toho Kabupaten Pontianak).

Darmiasaih. 2015. Analisis Makanisme Penyaluran Alokasi Dana Desa (ADD) Pada Pemerintah Desa (Studi Desa Tri Eka Buana, Kec. Sidemen, Kab. Karang asem).

Danaslah, Anja Firash Ipri. 2016. Implementasi Monitoring dan Evaluasi Direktorat Jendral Perimbangan Keuangan terhadap Penyerapan dan Penggunaan Dana Tranfer ke Daerah dalam Menunjang Belanja Daerah.

Iqsan. 2016. Tranparasi Pemerintah Desa dalam Penyusunan Anggaran Pendapatan dan Belanja Desa (APBDES) di Desa. Long Nah Kecamatan Muara Ancalong Kabupaten Kuntai Timur.

Kratasasmita. Ginanjar. 1994, Manajemen Pembangunan untuk Negara Berkembang.

Jakarta. PT Gelora Aksara Pratama.

Maleong. Lexy J. 2007, Metodologi Penelitian Kuantitatif Remaja Rosdakarya Offset. Bandung

Maleong. L.J (2012), Metode Penelitian Kuantitatif Edisi Revisi Bandung.

PT Remaja Rosdakarya.

Ompi. Antika Wulan. 2013. Implementasi Kebijakan Alokasi Dana Desa (add) Dalam Meningkatkan Pembangunan Desa (Studi di Desa Panggu. Kec.Ratakan Kab.Minahasa Tenggerang)

Pehlevi. Indra. 2015, Dana Desa dan Permasalahannya.

Peratutan Menteri Dalam Negeri No, 114 Tahun 2014 Tentang Pedoman Pembangunan Desa.

Peraturan Pemerintah No.47 Tahun 2015 Tentang Perubahan Atas Peraturan Pemerintah No.43 Tahun 2014 Tentang Peraturan Pelaksanaan Undang - Undang No.6 Tahun 2014 Tentang Desa.

Peraturan Menteri Dalam Negeri No.113 Tahun 2014 Tentang Pengelolaan Keuangan Desa. 
Peraturan Pemerintah No..60 Tahun 2014 Tentang Dana Desa yang Bersumber dari Anggaran Pendapata dan Belanja Negara.

Peraturan Pemerintah No.113 Tahun 2014 Tentang Pengelolaan dan Pertanggung Jawaban Keuangan Daerah.

Peraturan Pemerintah Dalam Negeri No.37 Tahun 2015 Tentang Pedoman Penyusutan Anggaran Pendaptan dan Belanja Daerah Tahun Anggaran 2015.

Peraturan Bupati Jember No.19 Tahun 2015 Tentang Tatacara Pembagian dan Penetapan Rincian Dana Desa di Kabupaten Jember Tahun Anggara. 2015.

Rosalinda. Okta. 2014, Pengelolaan Alakosai Dana Desa dalam Menunjang Pembangunan Pendesaan (Studi kasus: Segadarejo Dana Desa Ploso Karep. Kecamatan Sumobito, Kabupaten Jombag).

Sanusi, Anwar. 2001. Metode Penelitian Bisnis. Salembar Empat. Jakarta.

Sugiyono. 2010. Metode Penelitian Kualitatif dan R\&D. Alfabeta. Bandung.

Suminto, 2004, Pengelolaan APBD Dalam Sistem Manajemen Keuangan Negara.

Jakarta: Ditijen Anggaran, Depkeu.

Sieagian, Sedang P. (2004). Manajemen Sumber Daya Manusia. Jakarta: Bumi Aksara.

Surya, Ketrin. 2013, Evaluasi Penerapan Kebijakan Kepala Desa dalam Pengelolaan Administrasi Keuangan Desa Empunak Tapang Keladan. Artikel Peneitian.

Potianak: Universitas Tanjungpur.

Tjokromidjojo. B. (1996), Perencanaan Pembangunan. Edisi ke-19. PT Gunung Agung, Jakarta. 